\title{
STUDY OF ELEVATION OF SERUM HOMOCYSTEINE LEVEL IN ECLAMPSIA IN A SPECILIZED HOSPITAL SETTING IN BANGLADESH
}

\author{
MAHAL $\mathrm{M}^{1}$, HOSSAIN MS ${ }^{2}$, SULTANA N ${ }^{3}$, CHOWDHURY NS ${ }^{4}$, AMIN SAKMN $^{5}$
}

\begin{abstract}
:
Context: Eclampsia is one of the most leading causes of maternal deaths in developing countries. Many studies have demonstrated the relationship between hyperhomocysteinemia and eclampsia. The aim of this study was to examine the association between serum homocysteine with eclampsia.
\end{abstract}

Methods: A case control study carried out in the Department of Biochemistry, Dhaka Medical College, Dhaka. 50 diagnosed cases of eclampsia were taken as cases and 52 healthy women with uncomplicated pregnancy were taken as controls. Serum homocysteine was measured in all study subjects by fluorescence polarization immunoassay (FPIA) method.

Result: Serum homocysteine found to be significantly increased $(p<0.001)$ in patients with eclampsia $(10.44 \pm 4.08 \mu \mathrm{mol} / \mathrm{L})$ compared to controls $(7.97 \pm 3.46 \mu \mathrm{mol} / \mathrm{L})$.

Conclusion: It can be concluded that elevated serum homocysteine is associated with eclampsia.

Key words: Serum homocysteine, eclampsia.

J Dhaka Med Coll. 2010; 19(2) : 131-134.

\section{Introduction:}

Eclampsia is one of the most common complications of pregnancy. It is a cause of high mortality and morbidity for both mother and foetus, especially in developing countries ${ }^{1}$. Eclampsia is associated with $10 \%$ of maternal deaths and approximately 50,000 women die each year from this complication worldwide ${ }^{2}$. Bangladesh, like many other developing countries, is facing various health related problems including high maternal mortality (3.15 per 1000 women) ${ }^{3}$. In Bangladesh, the incidence of eclampsia is alarmingly high, for about $16 \%$ of maternal deaths are associated with it $^{4}$.

Aetiology of preeclampsia and eclampsia is still obscured. However, one of the most favoured hypotheses is the endothelial dysfunction secondary to the peroxidation of membrane lipids ${ }^{5}$. The vascular endothelium produces a number of important substances including endothelial derived relaxing factor (EDRF) or nitric oxide, endothelin-1, prostacyclins and tissue plasminogen activator. EDRF and prostacyclins are necessary for vasodilatation. With injury to endothelial cells these vasodilators are reduced. A decrease in EDRF release might be important in the pathophysiologic mechanism in preeclampsia ${ }^{6}$.

Homocysteine is a sulfur containing amino acid derived from the metabolic demethylation of dietary methionine. Most recently homocysteine has been claimed as a factor for vascular endothelial cell injury in preeclampsia and its consequences ${ }^{7}$. Homocysteine by auto oxidation generates

1. Dr. Monzarin Mahal, Lecturer, Department of Biochemistry, Dhaka Medical College, Dhaka.

2. Prof. Md. Shahadat Hossain, Professor \& Head, Department of Biochemistry, Sylhet MAG Osmani Medical College, Sylhet.

3. Dr. Nasima Sultana, Associate Professor, Department of Biochemistry, Dhaka Medical College, Dhaka.

4. Dr. Neelufar Sultana Chowdhury, Assistant Professor, Department of Biochemistry, Dhaka Medical College, Dhaka.

5. Lt. Col. (Dr.) Syed AKM Nurul Amin, Commanding Officer, 11 Field Ambulance, Savar Cantonment, Savar, Dhaka.

Correspondence: Dr. Monzarin Mahal, Lecturer, Department of Biochemistry, Dhaka Medical College, Dhaka. Cell Phone: +8801716369514, Email: monzarinmahal@yahoo.com 
super oxide and hydrogen peroxide, both of which damage the arterial endothelial lining or cause endothelial dysfunction. Such endothelial dysfunction results in decreased bioavailibity of nitric oxide, a vasodilator, antiplatelet aggregator, anti-inflammatory agent and inhibitor of smooth muscle cell growth ${ }^{8}$. Endothelial cell dysfunction appears to be a central feature in the pathophysiology of preeclampsia, leading to altered vascular reactivity, activation of the coagulation cascade, and loss of vascular integrity ${ }^{9}$. The homocysteine-mediated vascular changes are similar to those associated with pre-eclampsia. Therefore, a hypothesis has been proposed that hyperhomocysteinemia may be associated with this condition ${ }^{10}$.

Various studies have been carried out globally for searching the association between elevated homocysteine level and eclampsia. In Bangladesh, studies on homocysteine are very few in number. Hyperhomocysteinaemia might be an independent factor associated with eclampsia in Bangladeshi women as well. It could be possible to bring health benefits to our population by treating hyperhomocysteinemia, if it is proved to be associated with eclampsia. So, this study has been designed to explore the association between serum homocysteine with eclampsia and to establish serum homocysteine measurement as a reliable test for early detection of eclampsia.

\section{Materials and Methods:}

A case control study was conducted in the Department of Biochemistry, Dhaka Medical College, Dhaka, from July 2006 to June 2007. Total 102 pregnant non-smokers, free from preexisting hypertension, cardiovascular disease, cerebrovascular disease, diabetes mellitus, renal disease, liver disease and hypothyroidism were taken in the study. Among them 50 were diagnosed cases of eclampsia (Group-I) and 52 were matched normotensive healthy pregnant controls (Group-II). Subjects were selected from the Department of Obstetrics and Gynaecology, Dhaka Medical College Hospital, Dhaka. Study subject of both groups were apparently matched with respect to maternal age, gestational age and BMI. Informed written consent was taken from the patient/ attendant to the patient for each individual case. With all aseptic precautions, morning blood samples were collected from all the subjects. Serum was separated from centrifuged blood and stored at $-70^{\circ} \mathrm{C}$. Serum homocysteine concentration was analyzed by fluorescence polarization immunoassay (FPIA) method by Abbot's AxSYM system $^{11}$. The data were analyzed statistically by using SPSS version 12.0. Student's unpaired ' $t$ ' test was performed to see the differences between two groups. For all the statistical analyses 2 -tailed $P$ values $<0.05$ were considered as significant.

Ethical clearance: This research work was approved by the Ethical Review Committee of Dhaka Medical College, Dhaka.

\section{Results:}

For this study, 50 diagnosed eclampsia cases (Group-I) and 52 uncomplicated healthy pregnant controls (Group-II) were selected. The mean age of the cases was 25.30 \pm 5.49 years (ranging from 17 to 38 years) and the mean age of the controls was $26.75 \pm 4.83$ years (ranging from 17 to 40 years). The mean age of two groups were close and maintain no significant difference. The mean values of gestational age (in weeks) of case and control were $29.29 \pm 2.86$ and $30.08 \pm 2.80$ weeks respectively. There was no significant difference of gestational age between two groups. The mean BMI (in $\mathrm{kg} / \mathrm{m}^{2}$ ) of case and control were $25.04 \pm 1.01$ and $24.87 \pm 1.49$ respectively. There was no significant difference of BMI between two groups under study (Table-I).

The mean systolic BP of case was $150 \pm 14.22$ $\mathrm{mm}$ of $\mathrm{Hg}$ and control was $113.27 \pm 11.37 \mathrm{~mm}$ of $\mathrm{Hg}$. The mean diastolic BP of case was $104 \pm 8.92$ $\mathrm{mm}$ of $\mathrm{Hg}$ and control was $68.94 \pm 7.56 \mathrm{~mm}$ of $\mathrm{Hg}$. There was significant difference in both systolic and diastolic blood pressure between the groups (Table-II). The study revealed that the mean serum homocysteine concentration in cases was $10.44 \pm 4.08 \mu \mathrm{mol} / \mathrm{L}$ and in controls was $7.97 \pm 3.46 \mu \mathrm{mol} / \mathrm{L}$. Serum homocysteine concentration was significantly increased $(p<0.001)$ in eclampsia compared to control (Table-II). 
Table-I

Comparison of study subjects according to maternal age, gestational age and BMI

\begin{tabular}{lcccc}
\hline Variables & Case $(\mathrm{n}=50)$ & Control $(\mathrm{n}=52)$ & t- value & P- value \\
& Mean $\pm \mathrm{SD}$ & Mean $\pm \mathrm{SD}$ & & \\
\hline Age $(\mathrm{yrs})$ & $25.30 \pm 5.49$ & $26.74 \pm 4.92$ & & \\
& $(17-38)$ & $(17-40)$ & 1.418 & $>0.05$ \\
Gestational age (weeks) & $29.29 \pm 2.86$ & $30.04 \pm 2.84$ & & \\
& $(24-34)$ & $(22-36)$ & 1.457 & $>0.05$ \\
BMI $(\mathrm{kg} / \mathrm{m} 2)$ & $25.04 \pm 1.01$ & $24.92 \pm 1.50$ & & \\
& $(2.77-27.41)$ & $(22.19-29.52)$ & .664 & $>0.05$ \\
\hline
\end{tabular}

Table-II

Comparison of blood pressure status and serum homocysteine concentration between case and control

\begin{tabular}{lcccc}
\hline Variables & Case $(\mathrm{n}=50)$ & Control $(\mathrm{n}=52)$ & t- value & P- value \\
& Mean $\pm \mathrm{SD}$ & Mean $\pm \mathrm{SD}$ & & \\
\hline Systolic BP $(\mathrm{mm}$ of $\mathrm{Hg})$ & $150.60 \pm 14.22$ & $113.27 \pm 11.37$ & 14.75 & $<0.001$ \\
& $(130-180)$ & $(90-140)$ & & \\
Diastolic BP $(\mathrm{mm}$ of $\mathrm{Hg})$ & $104 \pm 8.92$ & $69.60 \pm 7.6$ & 21.44 & $<0.001$ \\
& $(90-120)$ & $(60-80)$ & & \\
Serum Homocysteine $(\mu \mathrm{mol} / \mathrm{L})$ & $10.44 \pm 4.08$ & $7.97 \pm 3.46$ & 3.179 & $<0.001$ \\
& $(4.73-17.10)$ & $(4.20-14.90)$ & & \\
\hline
\end{tabular}

Parentheses show the range. Student's unpaired' $t$ ' test was done for significance.

\section{Discussion:}

Preeclampsia and eclampsia complicates 7 $10 \%$ of all gestations ${ }^{12}$. Approximately $10-15 \%$ of maternal deaths in developing countries are associated with pre-eclampsia and eclampsia ${ }^{2}$. In Bangladesh, the incidence of eclampsia is alarmingly high, about $16 \%$ of maternal deaths are associated with it ${ }^{4}$. So it would be better to diagnose this disease before its clinical manifestations. The prevention of the onset of the disease would have a significant improvement in the maternal and child health. Many studies have demonstrated the relationship between elevated homocysteine and pre-eclampsia; or eclampsia 10, 13, 14, 15, 16, $17,18,19$. The mean serum homocysteine level was found to be significantly high $(p<0.001)$ in eclampsia as compared to their control value. The findings of the present study are consistent with those of Vanderjagt et al. ${ }^{1}$, Cotter et al. ${ }^{9}$, Rajkovic et al. ${ }^{14}$ and Hoque et al. ${ }^{19}$ as homocysteine concentration was found to be raised in eclampsia patients. Thus, elevated serum homocysteine appears to be a factor associated with eclampsia. It can be concluded from this study that increased homocysteine level is associated with eclampsia.

Folate, vitamin $\mathrm{B}_{12}$ and vitamin $\mathrm{B}_{6}$ are involved in the metabolism of homocysteine ${ }^{20}$. Elevated homocysteine is a marker of low B vitamin status or decreased methylation capacity of cells 21,22 . So, vitamin $\mathrm{B}_{6}, \mathrm{~B}_{12}$ and folic acid supplementation could have a role in preventing the elevation of homocysteine in pregnant women ${ }^{21}$. Early detection is the corner stone for proper management of eclampsia, which will reduce the maternal mortality rate and infant mortality rate. For early detection we are searching for a reliable, simple and inexpensive laboratory test. Serum homocysteine measurement can be used for this purpose. So, serial estimation of serum homocysteine from the $1^{\text {st }}$ trimester of pregnancy could be advised for early detection 
of preeclampsia and eclampsia. Pregnant ladies having increased homocysteine may bring under special management with the target to normalize their serum homocysteine with vitamin $\mathrm{B}_{6}, \mathrm{~B}_{12}$ and folic acid supplementation to prevent eclampsia. But the use of serum homocysteine measurement as a screening test for eclampsia warrants further investigation.

\section{References:}

1. Vanderjagt DJ, Patel RJ, El-Nafty AU, Melah GS, Crossey MJ, Glew RH. High density lipoprotein and homocysteine levels correlate inversely in preeclamptic women in northern Nigeria. Acta Obstet Gynecol Scand 2004; 83(6): 536-42.

2. Duley L. Maternal mortality associated with hypertensive disorders of pregnancy in Africa, Asia, Latin America and the Caribbean. Br J Obstet Gynaecol 1992; 99(7): 547-53.

3. National Census 2002. Bangladesh Bureau of Statistics. Ministry of Planning, Government of the People's Republic of Bangladesh. Dhaka, Bangladesh. 2004.

4. Rashid KM, Rahman M, Hayder S. Text book of community medicine and public health. $4^{\text {th }}$ ed. Dhaka: RHM publishers; 2004. p. 155.

5. Dekker GA, Sibai BM. Etiology and pathogenesis of pre-eclampsia: current concepts. Am J Obstet Gynecol 1998; 179(5): 1359-75.

6. Mabie WC, Sibai BM. Hypertensive states of pregnancy. In: AH DeCherney, ML Pernoll. eds. Current obstetric \& gynecologic diagnosis \& treatment. USA: Appleton and Lange; 1994. p. 380 .

7. Wang J, Brian J, Trudinger BJ, Duarte N, Wilcken DE, Wang XL. Elevated circulating homocysteine levels in placental vascular disease and associated pre-eclampsia. Br J Obstet Gynaecol 2000; 107(7): 935-8.

8. Welch GN, Loscalzo J. Homocyeseine and atherothombosis. N Engl J Med 1998; 338(15): 1042-50.

9. Cotter AM, Molloy AM, Scott JM, Daly SF. Elevated plasma homocysteine in early pregnancy: a risk factor for the development of severe preeclampsia. Am J Obstet Gynecol 2001; 185(4): 781-5.

10. Rajkovic A, Catalano PM, Malinow MR. Elevated homocysteine levels with preeclampsia. Obstet Gynecol 1997; 90(2): 168-71.
11. Refsum H, Smith AD, Ueland PM, Nexo E, Clarke $\mathrm{R}$, McPartlin J, et al. Facts and recommendations about total homocysteine determinations: an expert opinion. Clin Chem 2004; 50(1): 3-32.

12. Niyazi T, Hasnu C, Gurkan C, Oguz O, Ahmet A. The correlation between plasma homocysteine and malondialdehyde level in pre-eclampsia. Neuroendocrinol Lett 2003; 24(6): 446-8.

13. Walker MC, Smith GN, Perkins SL, Kelly EJ, Garner PR. Changer in homocysteine levels during normal pregnancy. Am J Obstet Gynecol 1999; 180(3): 660-4.

14. Rajkovic A, Mahomed K, Malinow MR, Sorensen TK, Woelk GB, Williams MA. Plasma homocysteine concentrations in eclamptic and preeclamptic African women postpartum. Obstet Gynecol 1999; 94: 355-60.

15. Ingec M, Borekci B, Kadanali S. Elevated plasma homocysteine concentrations in severe preeclampsia and eclampsia. Tohoku J Exp Med 2005; 206(3): 225-31.

16. Powers RW, Evans RW, Majors AK, Ojimba JI, Ness RB, Crombleholme WR, et al. Plasma homocysteine concentration is increased in preeclampsia and is associated with evidence of endothelial activation. Am J Obstet Gynecol 1998; 179(6): 1605-11.

17. Makedos G, Papanicolaou A, Hitoglou A, Kalogiannidis I, Makedos A, Vrazioti V, et al. Homocysteine, folic acid and $B_{12}$ serum levels in pregnancy complicated with preeclampsia. Arch Gynecol Obstet 2007; 275(2): 121-4.

18. Cotter AM, Molloy AM, Scott JM, Daly SF. Elevated plasma homocysteine in early pregnancy: a risk factor for the development of nonsevere preeclampsia. Am J Obstet Gynecol 2003; 189(2): 391-4.

19. Hoque MM, Bulbul T, Mahal M, Islam NAF, Ferdausi M. Serum homocysteine in pre-eclampsia and eclampsia. Bangladesh Med Res Counc Bull 2008; 34(1): 16-20.

20. Strain JJ, Dowey L, Ward M, Pentieva K, McNulty H. B-vitamins, homocysteine metabolism and CVD. Nutr Soc 2004; 63: 597-603.

21. Castro R, Rivera I, Struys EA, Jansen EE, Ravasco $\mathrm{P}$, Camilo $\mathrm{ME}$, et al. Increased homocysteine and S-adenosylhomocysteine concentrations and DNA hypomethylation in vascular disease. Clin Chem 2003; 49(8): 1292-6.

22. Patric TE, Powers RW, Daftary AR, Ness RB, Roberts JM. Homocysteine and folic acid are inversely related in black women in preeclampsia. Hypertension 2004; 43: 1279-82. 